\title{
Interaction between bradykinin and urodilatin - a possible mechanism of clinical relevance
}

\author{
Marina Dobrivojević ${ }^{*}$, Aleksandra Sinđić ${ }^{\prime}$ Bojana Nikitović ${ }^{1}$, Bayram Edemir ${ }^{2}$, Eberhard Schlatter ${ }^{2}$, \\ Wolf-Georg Forssmann ${ }^{3}$, Jochen R Hirsch ${ }^{3}$ \\ From 5th International Conference on cGMP: Generators, Effectors and Therapeutic Implications \\ Halle, Germany. 24-26 June 2011
}

\section{Background}

Bradykinin (BK) plays a significant role in pathophysiology of different diseases from angioedema to brain stroke and heart attack by inducing vasodilatation and increasing capillary permeability. We investigate the potential effects of natriuretic peptides on BK signaling by measuring membrane potential $\left(V_{\mathrm{m}}\right)$ of HEK293 cells using the whole cell patch clamp technique. HEK293cells are an excellent model since they display the natriuretic peptide receptor type $\mathrm{A}$ as well as both $\mathrm{BK}$ receptors (BR1 and BR2).

\section{Results}

Starting $V_{\mathrm{m}}$ was $-53.5 \pm 1.1 \mathrm{mV}, \mathrm{n}=184$. To detect viability of the cells hyperkalemic conditions were used (changing $\mathrm{K}^{+}$from $3.6 \mathrm{mM}$ to $18.6 \mathrm{mM}$ ) which depolarized HEK293 cells by $9.7 \pm 0.4 \mathrm{mV}, \mathrm{n}=182$. BK $(100$ $\mathrm{nM})$ depolarized HEK293 cells by $\Delta V_{\mathrm{m}}=3.0 \pm 0.2 \mathrm{mV}$,

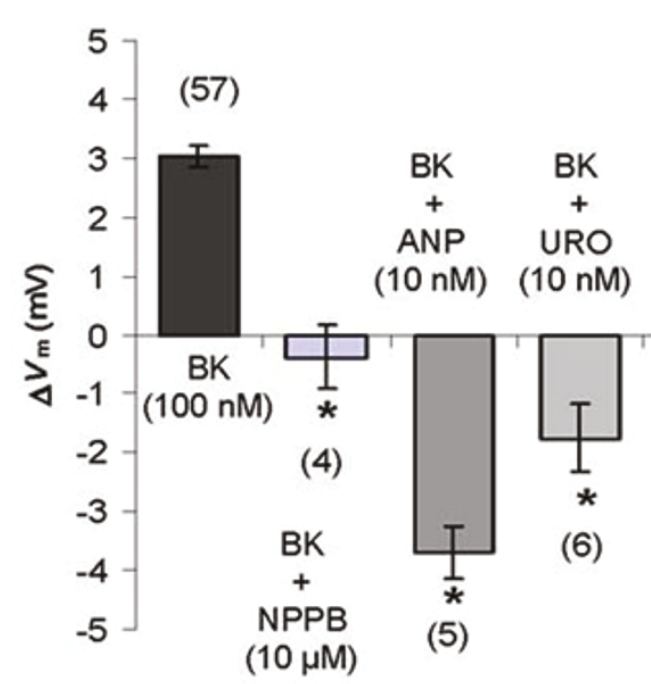

(4)

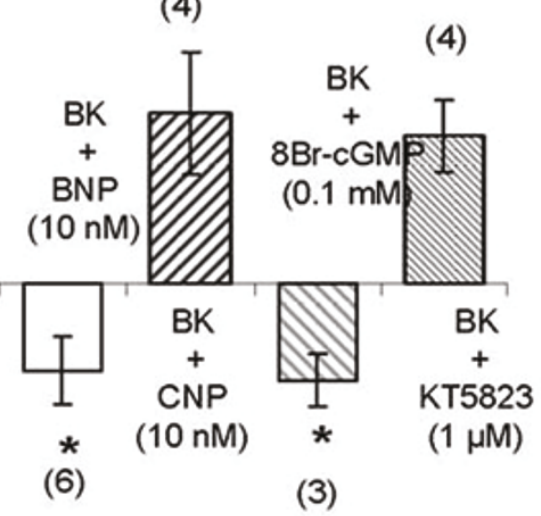

Figure 1 Effects of natriuretic peptides and CGMP signaling pathway on bradykinin (BK) action. BK - bradykinin; NPPB - inhibitor of Ca² +-dependent $\mathrm{Cl}^{-}$channels; ANP - atrial natriuretic peptide; URO - urodilatin; BNP - brain natriuretic peptide; CNP - C-type natiuretic peptide; KT5823 - inhibitor protein kinase G. Number of experiments are given in brackets. ${ }^{*} \mathrm{p}<0.05$ compared to depolarizations caused by bradykinin alone

\footnotetext{
* Correspondence: mdobrivojevic@gmail.com

'Dept. Physiology, School of Medicine, Croatian Institute for Brain Research,

University of Zagreb, Croatia, Rupublic of

Full list of author information is available at the end of the article
} 
$\mathrm{n}=57$ (figure 1). Our preliminary results show that the BK induced depolarization by activating bradykinin receptor type 2 (BR2) and further down the signaling pathway activation of $\mathrm{Ca}^{2+}$-dependent $\mathrm{Cl}^{-}$channels (Figure 1).

Natriuretic peptides display different effects on the BK-induced depolarization due to activation of $\mathrm{Ca}^{2}$ ${ }^{+}$-dependent $\mathrm{Cl}^{-}$-channels. While ANP, urodilatin, BNP (all acting though guanylate cyclase A) and 8-Br cGMP inhibited the BK-induced depolarization, CNP (acting through guanylate cyclase B) failed to do so (Figure 1). Effects of urodilatin on BK-induced deoplarization could be reversed by inhibiting protein kinase $G$ (using the specific inhibitor KT5823) suggesting an inhibitory role of natriuretic peptides via GC-A, cGMP and PKG in BK signaling.

\section{Conclusion}

From our results we could speculate that natriuretic peptides might display beneficial effects in different pathological conditions caused by BK.

\section{Acknowledgements}

These materials are based on work financed by the National Foundation for Science, Higher Education and Technological Development of the Republic of Croatia and the CardioPep Pharma GmbH, Germany.

\section{Author details}

'Dept. Physiology, School of Medicine, Croatian Institute for Brain Research, University of Zagreb, Croatia, Rupublic of. ${ }^{2}$ Universitätsklinikum Münster, Experimentelle Nephrologie, Münster, Germany. ${ }^{3}$ Cardiopep Pharma GmbH, Hannover, Germany.

Published: 1 August 2011

doi:10.1186/1471-2210-11-S1-P21

Cite this article as: Dobrivojević et al:: Interaction between bradykinin and urodilatin - a possible mechanism of clinical relevance. $B M C$ Pharmacology 2011 11(Suppl 1):P21.

\section{Submit your next manuscript to BioMed Central} and take full advantage of:

- Convenient online submission

- Thorough peer review

- No space constraints or color figure charges

- Immediate publication on acceptance

- Inclusion in PubMed, CAS, Scopus and Google Scholar

- Research which is freely available for redistribution

Submit your manuscript at www.biomedcentral.com/submit
C Biomed Central 